
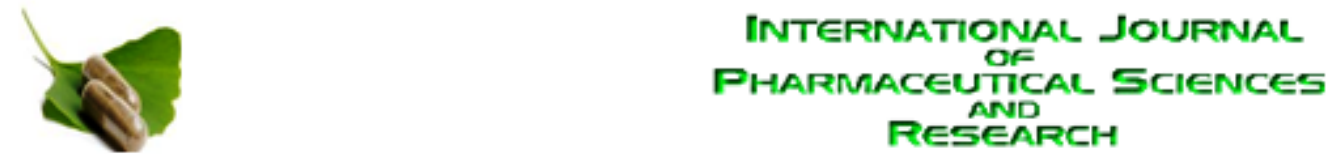

Received on 06 April, 2012; received in revised form, 02 December, 2012; accepted, 17 December, 2012

\title{
DEVELOPMENT AND VALIDATION OF A NEW HPLC METHOD FOR THE ESTIMATION OF AZITHROMYCIN IN BULK AND TABLET DOSAGE FORM
}

Irin Dewan* ${ }^{1}$, Tasnuva Amin ${ }^{1}$, Md. Faisal Hossain ${ }^{2}$, Moynul Hasan ${ }^{3}$, Sayeeda Fahmee Chowdhury ${ }^{1}$, Mahjabeen Gazi $^{1}$ and S.M. Ashraful Islam ${ }^{1}$

Department of Pharmacy, University of Asia Pacific ${ }^{1}$, Dhanmondi, Dhaka-1209, Bangladesh

Faculty of Pharmacy, University of Dhaka ${ }^{2}$, Dhaka-1000, Bangladesh

Department of pharmacy, Dhaka International University ${ }^{3}$, Banani, Dhaka-1213, Bangladesh

Keywords:

Azithromycin, Estimation, RP-HPLC,

Validation

Correspondence to Author:

Irin Dewan

Assistant Professor, Department of Pharmacy, University of Asia Pacific, Dhanmondi, Dhaka-1209, Bangladesh

E-mail: irin_d@yahoo.com

\begin{tabular}{|l|l|}
\hline QUICK RESPONSE CODE & IJPSR: \\
\hline ICV- 5.07 \\
\\
\hline
\end{tabular}

\section{ABSTRACT}

A simple, reproducible and efficient reversed phase high performance liquid chromatographic (RP-HPLC) method has been developed for quantitative determination of azithromycin in drug substance. The separations were carried out on a Xterra $\mathrm{C}_{18}$ column $(150 \times 4.6 \mathrm{~mm} ; 5 \mu)$ with UV detection at $215 \mathrm{~nm}$. The mobile phase consisting of acetonitrile and phosphate buffer ( $\mathrm{pH}$ adjusted to 7.5 ) in a ratio of $50: 50 \mathrm{v} / \mathrm{v}$. The injection volume was $50 \mu \mathrm{l}$ and flow rate was $1.0 \mathrm{~mL} / \mathrm{min}$. The linear dynamic response was found to be in the concentration range of $300 \mu \mathrm{g}-700 \mu \mathrm{g} / \mathrm{mL}$ and coefficient of correlation was found to be 0.998 . The \%RSD value was below 2.0 for intraday and interday precision indicated that the method was highly precise. The percentage recovery value was higher than $100 \%$, indicating the accuracy of the method and absence of interference of the excipients present in the tablet formulation. The proposed method was simple, economic, accurate, precise and reproducible and hence can be applied for routine quality control analysis of azithromycin in bulk and dosage form.
INTRODUCTION: Azithromycin is a macrolyte antibiotic that acts by interfering protein synthesis in bacteria. Due to the differences in the way proteins are made in bacteria and humans, the macrolyte antibiotics do not interfere with humans' ability to synthesis proteins. It binds to the 50s rRNA subunit of the 70s bacterial ribosome's, therefore inhibits RNA-dependent protein synthesis.

It inhibits the translation of mRNA in bacterial cells at the chain elongation step; result in the blockage of transpeptidation. Azithromycin is rapidly absorbed and is widely distributed to tissues and becomes concentrated in cells. Peak plasma concentrations are achieved within 2 to 3 hours ${ }^{1}$.
Chemically azithromycin is $(2 R, 3 S, 4 R, 5 R, 8 R, 10 R$, $11 R, 12 S, 13 S, 14 R)-13-[(2,6-D i d e o x y-3-C-m e t h y l-3-0-$ methyl- $\alpha$-L-ribo-hexopyranosyl)oxy]-2-ethyl-3,4,10trihydroxy-3,5,6,8,10,12,14-heptamethyl-11-[[3,4,6trideoxy-3-(dimethylamino)- $\beta$-D-xylo-hexopyranosyl] oxy]-1-oxa-6-azacyclopentadecan-15-one shown in figure 1.

It is derived from erythromycin; however, it differs chemically from erythromycin in that a methylsubstituted nitrogen atom is incorporated into the lactone ring ${ }^{2}$. 


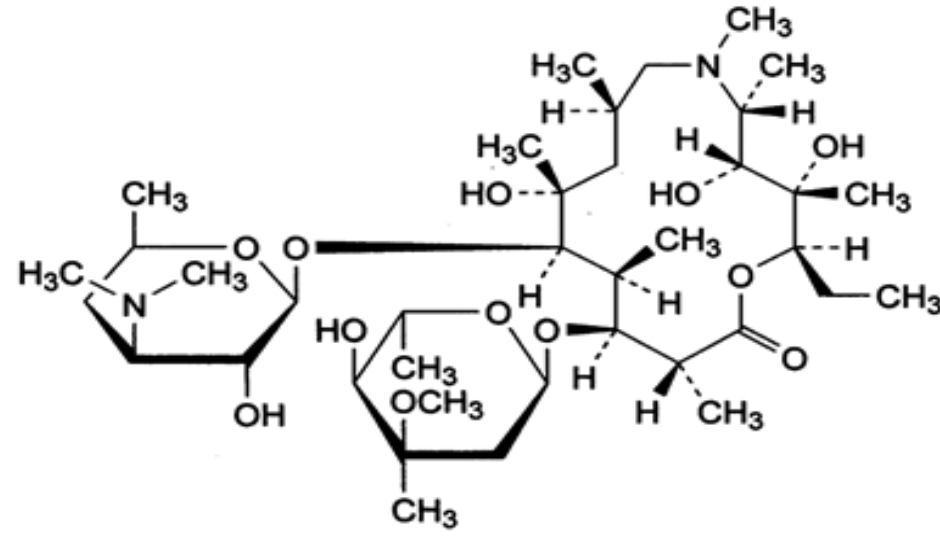

FIGURE 1: STRUCTURE OF AZITHROMYCIN

Azithromycin has been analyzed by HPLC using electrochemical ${ }^{3,4}$, fluorescence ${ }^{5}$, mass spectrometry 6 , and UV 7,8 for detection in bulk material and pharmaceutical forms. The USP method ${ }^{9}$ describes the use of a high $\mathrm{pH}$ mobile phase $(\mathrm{pH} 11.0)$ which requires the use of specific column which is expensive. Also USP method employs amperometric electrochemical detection which is not available in many laboratories. So development and validation of a simple method for the analysis of azithromycin is still required. In this study a new HPLC method has been developed for determination of azithromycin in bulk and tablet dosage forms which is very much simple, economic and accurate.

\section{MATERIALS AND METHODS:}

Apparatus and chromatographic condition: The chromatographic separation was performed on a Prominence Shimadzu high performance liquid chromatographic instrument equipped with a Xterra $\mathrm{C}_{18}$ column $(150 \times 4.6 \mathrm{~mm} ; 5 \mu \mathrm{m})$ integrated with UV detection at $215 \mathrm{~nm}$. The mobile phase consisting of acetonitrile and phosphate buffer ( $\mathrm{pH}$ adjusted to 7.5) in a ratio of 50:50 v/v and was prepared freshly, filtered and sonicated before use and delivered at a flow rate of $1 \mathrm{~mL} / \mathrm{min}$. The volume of each injection was $50 \mu \mathrm{l}$. Column temperature was maintained $40^{\circ} \mathrm{C}$ for the analysis.

Chemicals and reagents: Azithromycin was obtained as a gift sample from Renata Pharmaceuticals Ltd. Methanol and water used were of HPLC grade and phosphate buffer used were of analytical grade. The commercially available Azithromycin tablets claimed to contain $500 \mathrm{mg}$ of active ingredients were procured from local market of Bangladesh.
Preparation of Stock Solution: Stock solution of azithromycin was prepared by dissolving $100 \mathrm{mg}$ of azithromycin in a $100 \mathrm{~mL}$ of volumetric flask containing $50 \mathrm{~mL}$ of mobile phase and the solution was sonicated for $5 \mathrm{~min}$ and then volume was made up to the mark with mobile phase to get a concentration of $1.0 \mathrm{mg} / \mathrm{mL}$. Subsequent dilutions of this solution were made with mobile phase to get concentrations of 300 $\mu \mathrm{g} / \mathrm{ml}$ to $700 \mu \mathrm{g} / \mathrm{ml}$ and the chromatogram was recorded by maintaining the chromatographic condition shown in figure 3 .

Preparation of Sample Solution: A quantity equivalent to equivalent to $100 \mathrm{mg}$ of azithromycin drug substance was accurately weighed and transferred into a $100 \mathrm{ml}$ volumetric flask containing $50 \mathrm{~mL}$ of mobile phase and the solution was sonicated for $5 \mathrm{~min}$ and then made up to the mark with mobile phase to get a concentration of $1 \mathrm{mg} / \mathrm{mL}$. Then this solution was filtered through $0.45 \mu$ membrane filter and diluted suitably using mobile phase to obtain a solution 500 $\mu \mathrm{g} / \mathrm{mL}$.

Development and validation of HPLC method: Present study was conducted to obtain a new, affordable, cost-effective and convenient method for HPLC determination of azithromycin in bulk and tablet dosage form. The experiment was carried out according to the official specifications of USP-30, ICH1996, Global Quality Guidelines-2002. The method was validated for the parameters like system suitability, selectivity, linearity, accuracy, precision, and robustness.

The linearity of an analytical method is its ability to elicit that test results are proportional to the concentration of analyte in samples within a given range. This was determined by means of calibration graph using increasing amounts of standard solutions $(300-700 \mu \mathrm{g} / \mathrm{mL})$. These standards were tested six times in agreement to the International Conference on Harmonization (ICH).

Calibration curves were constructed and the proposed method was evaluated by its correlation coefficient and intercept value, calculated in the corresponding statistical study (ANOVA) $(p<0.05)$. 
The precision is a measure of the ability of the method to generate reproducible results. The precision of the assay was determined by repeatability (intraday) and intermediate precision (inter-day) and reported as $\%$ RSD. For this, $500 \mu \mathrm{g} / \mathrm{mL}$ of the solution was measured three times in a day and the same was repeated in next three days.

Accuracy indicates the deviation between the mean value found and the true value. Accuracy was determined by means of recovery experiments, by the addition of active drugs to placebo formulations. The accuracy was calculated from the test results as the percentage of the analyte recovered by the assay.

The system suitability tests were carried out on freshly prepared standard stock solution of azithromycin to evaluate the suitability of the system. The system was evaluated by analyzing the repeatability of retention time, tailing factor, theoretical plates (Tangent) of the column. The robustness of the method was assessed by altering the some experimental conditions such as, by changing the flow rate, amount of acetonitrile and the temperature of the column.

RESULTS AND DISCUSSION: All of the analytical validation parameters for the proposed method were determined according to Conference on Harmonization (ICH) guidelines ${ }^{10}$.

Linearity: The linearity of this method was determined at ten concentration levels ranging from 300$700 \mu \mathrm{g} / \mathrm{mL}$ (Table 1). The plot of peak area of each sample against respective concentration of drug was found to be linear shown in figure 2 in the range of $300-700 \mu \mathrm{g} / \mathrm{mL}$. The regression equation was found to be $\mathrm{Y}=2338.6 \mathrm{xs}-217080$ and the correlation coefficient $(r)$ of the standard curve were found to be 0.998 shown in table 2 .

\section{TABLE 1: DATA FOR CALIBRATION CURVE}

\begin{tabular}{cc}
\hline Concentration $\mu \mathrm{g} / \mathrm{ml}$ & Response of peak area \\
\hline 300 & 465924 \\
400 & 740912 \\
500 & 951350 \\
600 & 1194520 \\
700 & 1408426 \\
\hline
\end{tabular}

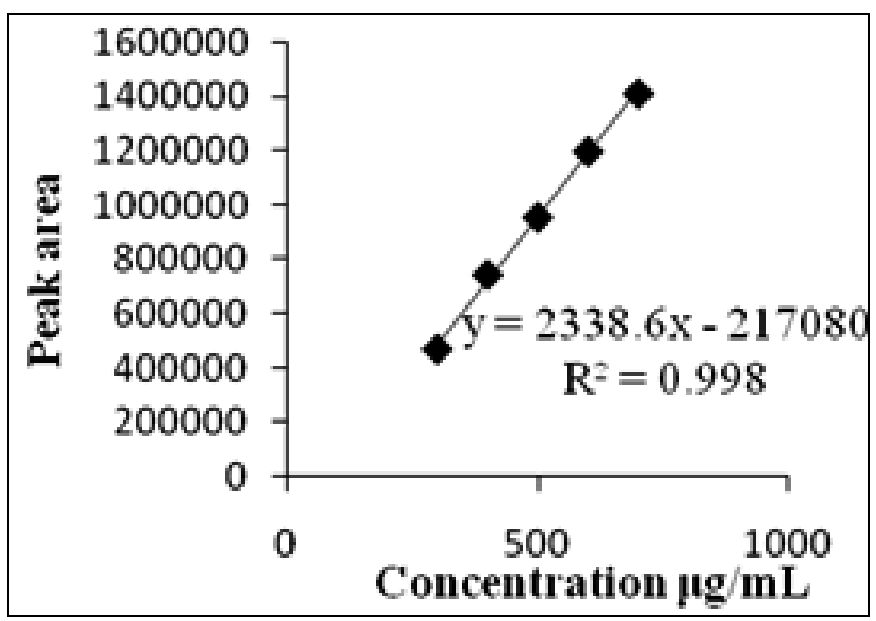

FIGURE 2: CALIBRATION CURVE OF AZITHROMYCIN

TABLE 2: VALIDATION PARAMETERS

\begin{tabular}{ccc}
\hline Parameters & \multicolumn{3}{c}{ Results } \\
\hline $\begin{array}{c}\text { Linearity range }(\mu \mathrm{g} / \mathrm{ml}) \\
\text { Standard Regression } \\
\text { equation }\end{array}$ & \multicolumn{3}{c}{300 to 700} \\
\cline { 2 - 4 } Correlation coefficient & \multicolumn{3}{c}{$\begin{array}{c}\text { Y } \\
\text { Precision }\end{array}$} & \multicolumn{3}{c}{$\begin{array}{c}\text { Contraday } \\
\text { Concentration }\end{array}$} & $\begin{array}{c}\text { Interday } \\
\text { (\%RSD) }\end{array}$ & \begin{tabular}{c} 
(\%RS) \\
\cline { 2 - 4 }
\end{tabular} & $500(\mu \mathrm{g} / \mathrm{ml})$ & 0.354 & 0.265 \\
\hline
\end{tabular}

Precision: The precision of the method was investigated with respect to repeatability (intra-day), intermediate precision (inter-day variation). The precision (measurements of intraday and inter day) results showed good reproducibility with percent relative standard deviation (\% RSD) was below $2.0 \%$ shown in table 2 . This indicated that method was highly precise.

Recovery studies (Accuracy): Recovery studies were performed to judge the accuracy of the method. The studies were carried out by adding a known quantity of pure drug to the pre-analyzed formulation and the proposed method was followed. From the amount of drug found, the percent recovery was calculated. Recovery study was carried out at three levels $80 \%$, $100 \%$ and $120 \%$ for the formulation concentration of $500 \mu \mathrm{g} / \mathrm{mL}$ shown in table 3.

The percentage recovery value which was higher than $100 \%$, indicated that the accuracy of the method and absence of interference of the excipients present in the tablet formulation. 
TABLE 3: RECOVERY STUDY

\begin{tabular}{cccc}
\hline Level of Addition (\%) & Addition of pure drug $(\boldsymbol{\mu g} / \mathbf{m L})$ & \% Recovery of pure drug & Recovery (\%) \pm S.D. \\
\hline 80 & 400 & 100.45 & $100.52 \pm 0.39$ \\
100 & 500 & 100.89 & \\
120 & 600 & 100.23 & \\
\hline
\end{tabular}

System Suitability Test: The parameters of system suitability study were presented in table 4 . From the typical chromatogram of azithromycin as shown in Figure 3, it was found that the average retention time \pm standard deviation for azithromycin was found to be $7.33 \pm 0.004 \mathrm{~min}$ for five replicate injections. The asymmetry factor was found to be 1.12, which indicated asymmetric nature of the peak. The number of theoretical plates was found to be 3639, which suggested an efficient performance of the column. The absence of additional peaks in the chromatogram indicated non-interference by the common excipients used in the tablet formulation. To optimize the chromatographic conditions, various combinations of acetonitrile and buffer were tested and the ratio of 50:50 v/v afforded peak with good shape and resolution.

\section{TABLE 4: SYSTEM SUITABILITY PARAMETER}

Retention time $(\min ) \pm S . D$.

No. of theoretical plates

$7.33 \pm 0.004$

Asymmetric factor
3629

1.12

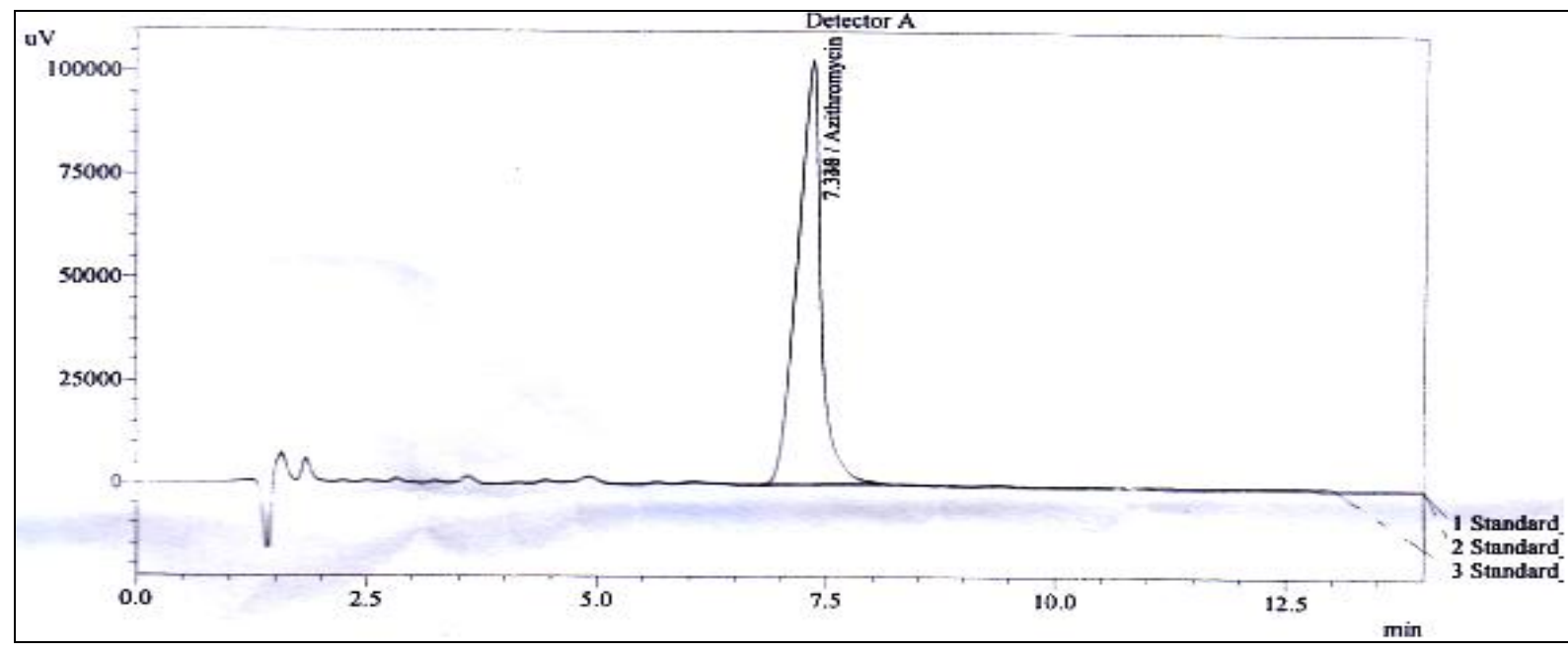

FIGURE 3: TYPICAL CHROMATOGRAM OF AZITHROMYCIN

Robustness: Robustness was performed by small but deliberate variation in the chromatographic conditions and was found to be unaffected by small variations like $\pm 2 \%$ in volume of mobile phase composition, \pm 0.1 $\mathrm{mL} / \mathrm{min}$ in flow rate of mobile phase and $\pm 1 \%$ change in column temperature. It was observed that there were no marked changes in the chromatograms, which demonstrated that the proposed method was robust.

CONCLUSION: From the above discussion it is clear that the proposed method was simple, sensitive and reliable with good precision and accuracy. Hence, this method can be used for the routine analysis of azithromycin in pure drug substance.
ACKNOWLEDGEMENTS: The authors are thankful to Centre for Advanced Research in Sciences, University of Dhaka for providing necessary facilities to conduct this research work.

The authors also like to acknowledge the support received from the Pharmaceutics Research Laboratory of the Department of Pharmacy, University of Asia Pacific.

\section{REFERENCES:}

1. Debremaeker D, Visky D, Chepkwony HK, Van Schepdael A, Roets $\mathrm{E}$ and Hoogmartens J: Analysis of unknown compounds in azithromycin bulk samples with liquid chromatography coupled to ion trap mass spectrometry. Rapid Communications in Mass Spectrometry 2003; 17: 342-350.

2. British pharmacopoeia. The Stationery Office, London, Fifth Edition 2011. 
3. Taninaka $\mathrm{C}$, Ohtani $\mathrm{H}$, Hanada $\mathrm{E}$, Kotaki $\mathrm{H}$, Sato $\mathrm{H}$ and Iga $\mathrm{T}$ : Determination of erythromycin, clarithromycin, roxithromycin and azithromycin in plasma by high performance liquid chromatography with amperometric detection. Journal of Chromatography 2000; 738: 405-411.

4. Kees F, Spangler S and Wellenhofer M: Determination of macrolides in biological matrices by high-performance liquid chromatography with electrochemical detection. Journal of Chromatography 1998; 812:287-293.

5. Sastre TJ and Guchelaar HJ: Quantitative determination of the macrolide antibiotics erythromycin, roxithromycin, azithromycin and clarithromycin in human serum by highperformance liquid chromatography using pre-column derivatization with 9-fluorenylmethyloxycarbonyl chloride and fluorescence detection. Journal of Chromatography 1998; 720: 89-97.
6. Zubata HG and Schneider RP: Quantitative Determination of the Antibiotic Azithromycin in Human Serum by High-Performance Liquid Chromatography (HPLC)-Atmospheric Pressure Chemical Ionization Mass Spectrometry: Correlation with a Standard HPLC-Electrochemical Method. Therapeutic Drug Monitoring 1995; 17(2):179-183.

7. Yubata $P$, Ceresole R, Rosasco MA and Pizzorno MT: A new HPLC method for azithromycin quantitation. Journal of Pharmaceutical and Biomedical Analysis 2002; 27: 833-836.

8. Kovacic-Bosnjak N, Marcinel J, Lopotar N and Kobrehal G: Analysis of azithromycin and its related compounds by reversed-phase high-performance liquid chromatography with UV detection. Chromatographia 1998; 11:999-1012.

9. United States Pharmacopeia. National Formulary, Rockville, 26th edition 2007.

10. ICH guidelines-validation of analytical procedure: text and methodology, 2011.

How to cite this article:

Dewan I, Amin T, Hossain MF, Hasan M, Chowdhury SF, Gazi M and Islam SMA: Development and Validation of a new HPLC method for the estimation of Azithromycin in Bulk and Tablet Dosage Form. Int J Pharm Sci Res. 2013; 4(1); 282-286. 